\title{
The Politics of Eco-violence: Why Is Conflict Escalating in Nigeria's Middle Belt?
}

Ezenwa E. Olumba

Royal Holloway, University of London.

\begin{abstract}
Competition for natural resources has intensified in recent years between nomadic Fulani herders and sedentary farmers in Nigeria's Middle Belt. What were initially sporadic conflicts over cropland and water have transformed into daily occurrences of mass violence. While extant research focuses on the root causes of such conflicts, the reasons for their escalation remain insufficiently understood. Based on fieldwork conducted in Nigeria during 2018-2019, this article examines how political developments have contributed to the escalation of conflict in the region. Using Homer-Dixon's theory of civil strife as a conceptual framework, the findings show that changes in the 'political opportunity structure' in Nigeria since 2014 were a catalyst for escalating the conflicts. These changes resulted from the 2014 insecurity in Nigeria caused by terrorist acts committed by non-state actors and the outcomes of the 2015 election. The consequences were the unvarnished adoption of nepotistic domestic policies and alliances between elites and militia members, which resulted in escalating violent conflicts in the Middle Belt.
\end{abstract}

Keyword: Farmer-herder conflicts, Middle Belt, Political opportunity structure, Nigeria, Ecoviolence. 


\section{Introduction}

On the 27th of April 2021, gunmen attacked the Abagana Internally Displaced People (IDP) camp, killing seven people. Reacting to this incident, Mr Samuel Ortom, Governor of Benue State, accused the Nigerian president of being a sectional president of the Fulani people (1). The President responded that the ongoing killings and violence in Benue State resulted from Mr Ortom's refusal to adopt 'RUGA policy' ${ }^{1}$ and urged him to adopt it for the sake of peace (2). A few days later, as if exonerated by the President's comments, Fulani gunmen attacked a Tiv community in Benue State, killing eleven people and displacing hundreds more (3). These mass killings are unrelated to the Boko Haram terrorist attacks, but to a deadlier conflict (4), which some have dubbed the 'deadliest conflict you have never heard of' (5). It is the so-called 'herder/farmer' conflict.

Since the beginning of the twenty-first century, civilians have outnumbered armed combatants as conflict victims (6), a trend that is reflected in the significant rise in the frequency of nonstate conflicts globally, for example, the farmer-herder conflicts in Nigeria (7). Indeed, there are no specific battlefields in these 'new wars' (8), but rather a spread of violence by non-state actors dispersed across the entire population of the targeted groups $(6,9)$. The farmer-herder conflicts are not limited to Nigeria. The competition over water and fertile land has caused intractable conflicts between nomadic Fulani herders and sedentary farmers in Ghana, Mali, Niger, Mauritania, Côte d'Ivoire and Senegal, particularly since the droughts of 1972-1973 and 1983-1986 (10-13). Much of these conflicts can be understood as 'eco-violence', or violent conflict between two or more groups - primarily, but not exclusively, non-state actors - in competition over access and control of scarce natural resources like water, fertile land, and crops $(14,15)$. The competition for fertile land was a significant cause of the 1989 SenegalMauritania conflict $(16,17)$, and the struggle for river access was one of the causes of Israel's six-day war with Arab countries in 1967 (18). Eco-violence occurs within a profoundly multiethnic society. While at times the conflict involves actors sharing the same ethnic identity, as observed between the Igbo (19), Yoruba (20), and Ebira (21) communities, and the nomadic Fulani herders $(22,23)$. The most intractable conflicts are between different ethnic communities, such as Tiv farmers and Fulani herders $(24,25)$.

In Nigeria, the Middle Belt is the most affected region (26,27). Figure 1 shows the regions with high intensity of eco-violence in Nigeria. The Nigerian Middle Belt includes federal states such as Benue, Plateau (now, Nasarawa and Plateau), Kwara, Kogi, Southern Kaduna, Federal Capital Territory and other towns in Niger Adamawa and Taraba states (28). The Middle Belt has an estimated population of over 30 million people ${ }^{2}$, inhabited mainly by people from the Tivs, Idomas, Berom, Jukuns, Mambila ethnic groups, who are primarily sedentary farmers $(28,29)$. More deaths have occurred because of eco-violence in the Middle Belt than the number of people killed by Boko Haram - a militant Islamist group - in the last decade in Nigeria $(4,30)$. Annual reports by reputable non-governmental organizations (NGOs) and think tanks show a heightened focus on Boko Haram's activities in the Northeast, despite the carnage associated with eco-violence in the Middle Belt and other regions. 


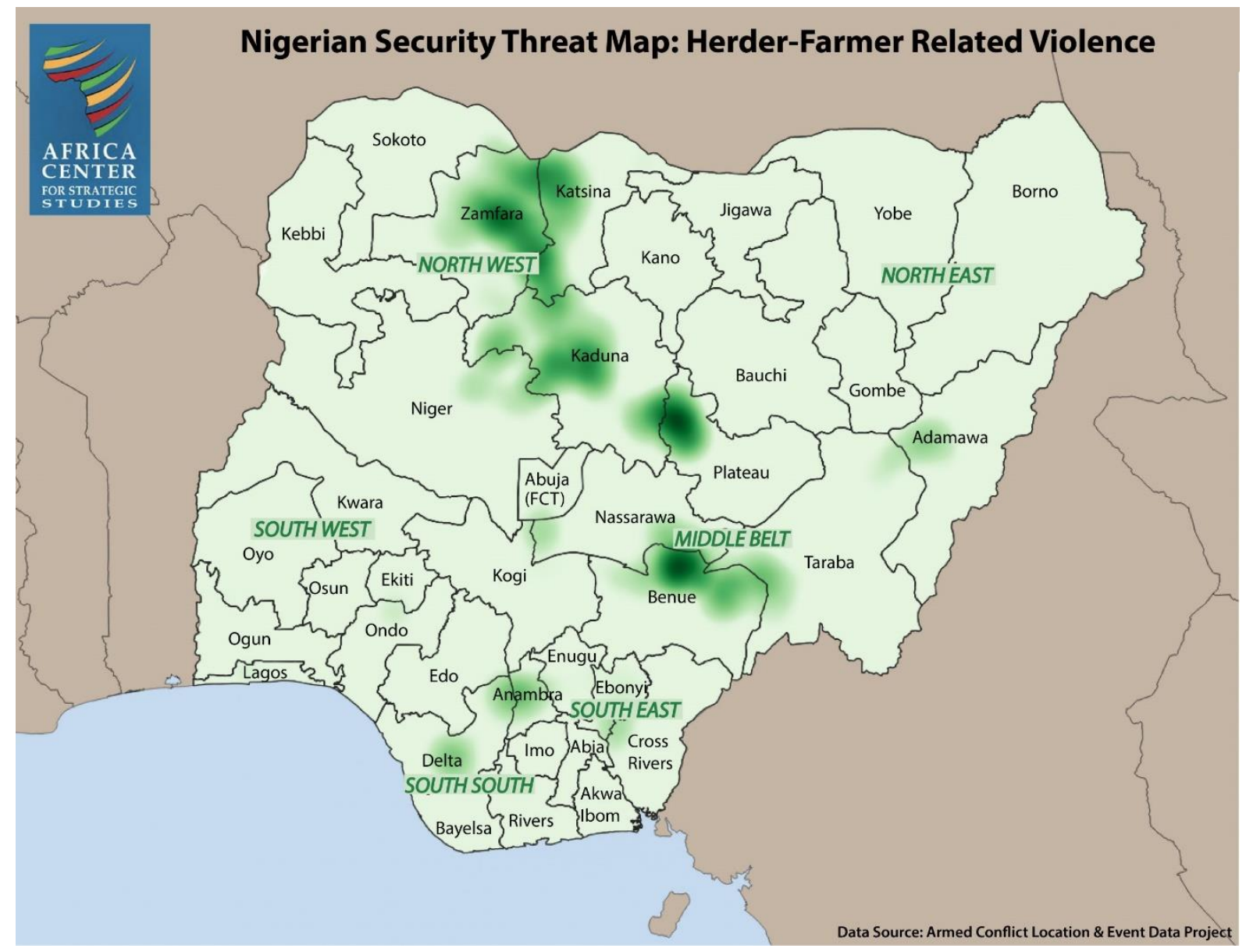

Figure 1.

Source: (31)

The severity of eco-violence in recent years in Nigeria are unprecedented and have left thousands of people killed, properties worth millions of US dollars destroyed $(32,33)$. As of 2014, approximately 11,700 people were killed in eco-violence related conflicts in Benue State, according to Vanger and Nwosu (34), citing a Benue State government report. According to a published IOM report, there were a total of 309,231 people displaced in the Middle Belt, and $204,193^{3}$ of them were displaced because of communal conflicts in Benue State alone, making it the highest number of IDPs in a state in Nigeria (35). Benue state was selected for this study because it is the most affected part of the Middle Belt in terms of the intensity and severity of eco-violence in that state (4).

The significant debates on the causes of eco-violence have typically focused on how adverse climatic conditions have created scarcity and unfavourable living conditions for herders, necessitating their migration into farming communities already constrained, resulting in conflict (36-38). Others argue that it is not scarcity but abundance and economic opportunities that create the conditions for these conflicts to erupt $(12,39)$. Structural factors like land-use systems and contradictory regulatory frameworks have been identified as factors responsible for these conflicts $(34,40,41)$. These issues have been exacerbated by ethnicity and exclusionary practices (42). Insecurity and the emergence of 'ungoverned spaces' are also fuelling these conflicts $(4,43)$. Recently, corruption related to the vested interests of agro investors and elites has emerged as additional critical factors in the recent upsurge of ecoviolence $(10,44)$; likewise, the framing, construction, and representation of people's lives and the conflicts over water and grazing fields $(24,41,45)$. 
This article departs from those approaches to investigate how political developments in Nigeria's Middle Belt since 2014 have contributed to the escalation of eco-violence. Since 2014, these conflicts have morphed from sporadic flare-ups into almost daily occurrences of mass violence $(46,47)$, and Benue state is its epicentre (25). The focus is specifically on conflicts between the Tiv farming communities and Fulani herders in Benue State, drawing on information obtained from ten semi-structured stakeholder interviews, four community-based focus group discussions, as well as from secondary sources.

Adopting conceptual insights from Homer-Dixon's theories of civil strife - that groups of actors will resort to eco-violence to address grievances when faced with increases in deprivation and favourable political opportunities (14), this paper seeks to understand why the conflict in Nigeria's Middle Belt is escalating? It argues that the changes in the 'political opportunity structure' in Nigeria since 2014, exemplified by the emergence of a new breed of government officials and pronounced collaborations between the elites and militias, have resulted in nepotistic domestic policies and impunity for violent militia groups. The political opportunity structure can be described as characteristics of a regime or government that provide opportunities and impediments to system actors, and a change in those features alters who receives favours or is constrained (48).

The article argues that these changes favoured the Fulani herders, who saw it as an opportunity to address their grievances against the farming communities in the Middle Belt. Such collective violent actions have resulted in reprisal attacks from Tiv communities and counter-reprisal attacks from both sides, resulting in widespread violence in the Middle Belt. In doing so, this article enhances the analytical strength of Homer-Dixon's interpretation of the relative deprivation theory and structural theories of civil strife by introducing the concept of political opportunity structure. Taken together, these results contribute to broader debates on ecoviolence by providing a more convincing account behind its escalation in recent times.

The article proceeds by describing the debate over the links between environmental resource scarcity, migration, and conflict. It then presents Homer-Dixon's interpretations of relative deprivation theory and structural theories of civil strife, arguing for the need to adapt his framework with the concept of the political opportunity structure. Following this, the article describes current debates on the causes of eco-violence in West Africa and methods used for the research. Lastly, it shows how changes to the political opportunity structure have driven the escalation of eco-violence in the Middle Belt since 2014.

\section{Environmental Scarcity, Migration and Conflict}

The debate on the links between environmental resource scarcity, migration and conflict can be separated into the neo-Malthusian and Cornucopian schools of thought. Neo-Malthusians argue that population growth, environmental degradation, inequality in resource distribution, and an inability to adapt to such pressures have resulted in demand outstripping the supply of natural resources $(14,49)$. This scenario leads to constrained agricultural productivity, migration, and social segmentation, fomenting conflict between different social groups. Several scholars argue that the migration of the Fulani across the Sahel and their involvement in Middle Belt violence fits the neo-Malthusian narrative $(13,37)$.

Some scholars have criticised the neo-Malthusian model of the 'Toronto group' work, led by Prof Homer-Dixon. For example, they exaggerated the effects of population growth and environmental shortages on the outcome of a conflict (50). In addition, they ignored the 
historical and structural dimensions of violence (51). Furthermore, that they use case studies in which there is environmental degradation and violent conflict, rather than including cases without conflict where a forecast might be possible or not $(50,52)$. And their theoretical model excluded factors related to politics and economics and their impacts on conflict eruptions (50).

The Cornucopian school contends that pressures on renewable resources foster the pursuit of technical knowledge to alleviate the problem of resource scarcity. Population pressure is thus conceived as a factor that boosts innovation, leading to economic prosperity and the deterrence of conflict $(53,54)$. Cornucopians also highlight a lack of evidence causally linking environmental pressures and scarcity to conflict $(53,55)$. It is the abundance of resources, rather than scarcity, that fuels conflicts (15). Studies within West Africa concur with this argument $(12,56)$. Neo-Malthusians and Cornucopians alike are criticized for overlooking structuralhistorical factors in the nexus of resource scarcity, conflict and migration $(51,57)$. For instance, Matthew suggests that scholars must view violent conflict linked with population growth and environmental scarcity in the context of political history and structural forms of violence to avoid overlooking the effects of colonialism and economic globalisation (51).

The analysis in this article hinges on Homer-Dixon's interpretations of relative deprivation theory and structural theories of civil strife - to be referred to as the Homer-Dixon Model and was supported by arguments from the concept of the political opportunity structure. The relative deprivation theory and structural theories of civil strife - '(...) suggest that insurgency is a function of both the level of grievance motivating challenger groups and the opportunities available to these groups to act violently on their grievances' (14 italics in original). An increase in a group's sense of relative deprivation tends to increase their grievance level at the same time, and '... if the group perceives that the structure of power relations surrounding it has changed in its favor, then it will perceive greater opportunities to address its grievances' (14 italics added). In other words, groups experiencing collective grievances will strive to recover their assumed deprived resources once favourable opportunities emerge.

A recent report ${ }^{4}$ on the Sahel region coheres with Homer-Dixon's theories. It points to increased exposure of the region to climate change and its aftermaths (58). The report asserts that resource availability, seasonal fluctuations, droughts, and floods alter pastoral migration routes, increasing the likelihood of conflict between herders and farmers. Although the report agrees with the Cornucopians that there is no clear causal link between climate change and conflict, they assert an exacerbation of existing tensions and vulnerabilities through climate change interactions with political, social, and environmental factors. This report mirrors the arguments about the circumstances necessitating the plight of the Fulani herders and the farmers in the Middle Belt $(43,59)$.

'By making some people poorer and weaker and others and more powerful, by causing people to move to new locations where they are often not wanted, and by weakening key institutions such as the state, environmental scarcity boosts grievances and changes the structure of opportunity facing the challenger groups' (60).

In other words, environmental scarcity causes inequality, migration to potentially hostile areas, and depreciation of political institutions, thereby exacerbating grievances and altering the opportunities available to the aggrieved group. Environmental scarcity depicts 'scarcity of renewable resources, such as cropland, forests, river water and fish stocks' and could result from resource depletion (supply instigated scarcity), over demand caused by population growth 
and over-consumption (demand instigated) and unequal distribution (structural scarcity) (14). However, ethnic cohesion within a group, 'advantageous opportunities', and resource mobilisation are thought to increase the likelihood of conflict erupting between contending groups $(61,62)$.

Incorporating the concept of the political opportunity structure into Homer-Dixon's model hones its analytical strengths in processing the impact of political factors such as government policies, political instability, and political behaviour on conflict. Thus, this article could analyse the effects of political factors and the aftermath of environmental scarcity to explain the reasons for the escalation of eco-violence in the Middle Belt. Therefore, this paper enhanced the analytical strength of Homer-Dixon's model with the concept of political opportunity structure, thereby, jointly, elevating the effects of political factors, grievances, and resource scarcity in explaining issues related to eco-violence.

The political opportunity structure can be described as the 'general features of a regime [which] affect the opportunities and threats impinging on any potential maker of claims, and changes in those features produce changes in the character of contention' (48). The political opportunity structure indicates periods of struggle in the political environment that either impede or promote groups engaged in contentious politics (63). This descriptions of the political opportunity structure is consistent with the argument of Homer-Dixon, that any event or process that severely undermines the incumbent political structure's program creates political opportunities (14).

The political opportunity structure has been described as the 'feature' of a regime (48), as the aftermath of events or social processes (14), and also as an indication of periods of changes in the political system (63). The common themes in these definitions are 'opportunities' and 'constraints' offered in the political system. These definitions highlight some critical aspects of the political opportunity structure: the emergence of a new regime with changes that alter who gets favoured or not among the contending groups within a certain period.

\section{Eco-violence in the Sahel}

The consequences of adverse climatic conditions and the impact of structural factors like government policies have been at the centre of the debate on the causes of eco-violence in West Africa. Recently, attention has shifted to how the vested interests of agricultural investors and elites and issues related to the framing and representation of people are shaping these conflicts.

Droughts and desertification, for example, have been argued to cause resource scarcity and climate-induced migration from the Sahel regions of Africa into the Guinea savannah and rain forest parts, potentially resulting in conflict between herders and farmers (36-39). Others contend that the abundance of resources, not scarcity, fuels conflict. Studies in Ghana and the 1989 Senegal-Mauritania crisis argue that abundance, not resource scarcity, caused conflict $(12,56)$.

Within the communities, uncompensated crop and farm damage by cattle, uncontrolled grazing, rape incidents, pollution, and mass murder are the farmers' grievances, which lead to conflict with the herders $(64,65)$. The herders' grievances among the causes of eco-violence are harassment in the host communities, cattle rustling, loss of lives, and denial of access to grazing fields (65-67). States' failures enable the emergence of ungoverned spaces that are conducive atmospheres for the proliferation of conflict $(4,43,46)$. The proliferation of military- 
grade weapons fuels and elongates these conflicts $(10,46)$. The Federal Government of Nigeria and some state governments' responses to eco-violence are prolonging these conflicts $(33,36,66)$. For instance, the promulgation of anti-open grazing law by some state governments and the Federal government's insistence on procuring grazing reserves for the Fulani herders are fuelling eco-violence $(33,66)$.

Land-use systems, exclusionary practices and contradictory regulatory frameworks have been attributed to the factors causing eco-violence in Nigeria, Ghana, and within the Sahel region, especially between Fulani herders and sedentary farmers $(11,34,45,68)$. Among Nigerians, such socio-economic exclusions include the dichotomous classifications of some people, such as farmers as 'indigenes' and Fulani herders as 'settlers' $(42,45,66,68)$.

The framing, construction and representation of people and conflicts have shaped the nature of these conflicts. The perception of Fulani herders as strangers and savages who have no rights to the land; likewise, the idea that farmers are indigenous and own the land, are among the contributing factors to the conflicts $(11,24,65)$. Such framing has led to the perception of these conflicts in terms of a Fulanisation, securitisation and sedentarisation process $(47,69)$.

Studies have identified the activities of investors in commercial agriculture and the interests of the elites as critical factors shaping the recent upsurge of eco-violence $(10,39,44)$. Rather than issues related to the climate, it is the elites' selfish interests that fuel conflict.(44). Eco-violence and cattle rustling have increased in recent years due to the emergence of neo-pastoralism (10). Neo-pastoralism is a type of large-scale cattle ownership by non-pastoralists who employ paid pastoralists who use automatic rifles to herd cattle across Nigeria, with the primary goal of laundering illicit funds and profit (10). The Fulani herders' persistence not to abandon open grazing discarding calls to adopt modern animal husbandry practices is a multiplier of ecoviolence (46). The escalating patterns of conflicts in the Middle Belt emerged in $2014(7,46,47)$ and the introduction of automatic firearms made it possible $(10,46)$. Yet, apart from a few studies $(10,46)$, the literature is yet to engage adequately with the factors acting as catalysts for the unprecedented escalation of eco-violence in Nigeria. Thus, this paper explored the political developments since 2014 in Nigeria to understand the factors shaping the almost daily occurrences of mass violence in the Middle Belt.

\section{Methods}

The study employed qualitative research methods consisting of eight focus group discussions (FGDs), six semi-structured interviews and field notes from two fieldwork conducted in Nigeria (April 2018 \& January 2019). The secondary data were derived from the Uppsala Conflict Data Program - UCDP, academic journals, books, and relevant newspaper reports. The purposive sampling method was used in selecting the respondents and locations for the focus group discussions and semi-structured interviews. The selections were based on the relevance of the respondents and locations to the research question (70). Four focus group discussions were conducted with the displaced Tiv farmers at the Abagana and Daudu IDP camps, whereas the other four focus group discussions were done at the International cattle Market, North Bank, Makurdi with Fulani cattle owners and representatives of the Myetti Allah Cattle Breeders Association. Each focus group discussion session had a minimum of seven and a maximum of ten participants. In addition, six semi-structured interviews were conducted with stakeholders in the affected communities: clergymen, officials of the government, and security personnel. The questions asked in the field were to understand the reasons for escalating the conflict to an unprecedented level. Using Braun and Clarke's thematic analysis technique to 
analyse the transcribed interview data and field notes, two themes that emerged formed the basis for discussing the reasons for the escalation of eco-violence (71).

\section{The Escalation of Eco-violence in Nigeria's Middle Belt since 2014}

According to Homer-Dixon's model, transformations that occur within societies because of environmental scarcity, social or political processes result in an alliance of political actors, the emergence of new regimes, and political instability, thereby increasing or decreasing the chances of contending groups to act $(14,48,63)$. In the Nigerian context, the 2014 insecurity situation in Nigeria $(72,73)$ led to shifts in the political opportunity structure. The synergy of the political forces of the Northern and Western parts of Nigeria in the 2015 general elections culminated in favourable election results for the opposition party led by General Muhammadu Buhari $^{5}$ and the removal of Dr Goodluck Jonathan as president $(72,73)$. As a result, a new breed of government officials has emerged at the highest levels of government, and collaborations between elites and militants have grown more pronounced and flourished. Thus, the cost of collective actions is lowered, and increased impunity for the favoured group. The most significant effect of the shift in Nigeria's political opportunity structure is the entrenchment of unvarnished nepotistic domestic policies, reinforced by collaborations between the elites and militias, to produce an escalation of eco-violence among the Fulani herders and the Tiv farmers.

\section{Change in the Opportunity Structure}

Prior to the March 2015 elections, the security situation in Nigeria deteriorated, and the security apparatuses became overwhelmed (72). A period in which the Boko Haram terrorist group seized control of 14 local government areas, covering an area the size of Belgium (74) and kidnapped the Chibok girls $(73,75)$. When governments fail to provide security, non-state actors and criminals utilize this 'security gap' or security vacuum to their advantage by carrying out violent activities (76). Consequently, non-state actors, like the Fulani herders, utilised such opportunities to address their grievances, culminating in reprisal attacks by the Tiv militia and counter-reprisal attacks from both sides. Men who move in groups on motorbikes perpetrate these attacks using automatic rifles like the AK47 assault rifle (77). These issues were among the reasons for the high death rates recorded in 2014 in the Middle Belt. Whereas the Fulani militias killed 63 people in 2013, in 2014, it was over 1,229 people, making them be labelled as the fourth deadliest terrorist group in the world in 2014 (78).

A shift in the political opportunity structure emerged in Nigeria when Dr Goodluck Jonathan lost his re-election bid, and General Muhammadu Buhari became the president of Nigeria. With the emergence of President Buhari, an escalation in the attacks and a rise in the number of deaths started emerging in eco-violence related attacks recorded in Benue state. The overbearing and nepotistic domestic policy objectives of the Buhari regime was encapsulated in the answers to the question ${ }^{6}$ posed to him, he stated that:

I hope you have a copy of the election results. The constituents, for example, gave me $97 \%$ [of the vote] cannot in all honesty be treated on some issues with constituencies that gave me 5\%. I think these are political reality (79).

In other words, people from areas, regions and ethnic nationalities who overwhelmingly voted for him will not be given the same opportunities as those who gave him little or no votes. This rhetoric concurs with the argument that elections offer a shift in political opportunity structure, consequently, the opportunity to reward supporters and even identify political opponents that 
will be unfairly treated (48). The president of Nigeria's stance on issues carries immense weight and consequences because he is constitutionally mandated with enormous resources and influence, including the control of the army, the police, and the appointment of the heads of over 700 parastatals (73).

President Buhari has appointed primarily Muslim men from the Northern parts of Nigeria as heads of almost all the security agencies and leaders of sensitive government ministerial agencies in Nigeria, giving advantage to these groups, especially the Muslim Hausa and Fulani people $(80,81)$. It has been argued that the appointments were impartial based on the information from the Federal Character Commission (FCC) (82). The leadership ${ }^{7}$ of the FCC is appointed by the Presidency (82). Nonetheless, Fasan's argument is based on the notion that it is not quantity but the quality that matters (80); six of Nigeria's eight security agencies are led by Muslim Northerners (the army, air force, police, national intelligence agency, and state security service). In contrast, only two positions were given to officers from the southern parts of Nigeria - the chief of defence staff and chief of naval staff. Some argue that $99.99 \%$ of federal ministers and heads of government agencies in Nigeria are of Fulani ethnicity (83). I cannot entirely agree with the $99.99 \%$ figure but concur with the narrative that Muslim men from the northern parts - Fulani, Hausa, and Kanuri men - lead most strategic and critical federal ministries, security agencies, and paramilitary organizations in Nigeria. Most Nigerians believe Buhari is a Fulani man, but Prof Kperogi argues that he is not culturally or linguistically Fulani even though his dad was Fulani because he grew up with his maternal Kanuri people (84). In Nigeria, people's indigenous status is connected to their patrilocal ancestry (85).

It is not only the appointments that are lopsided but also the siting of infrastructural development projects. For instance, in an interview with Arise TV on June 10, 2021, President Buhari justified his government's decision to build a $\$ 1.9$ billion rail project (86) linking Kano State in Nigeria to Maradi in the Niger Republic by saying, 'I have cousins, family members, etc., in the Niger Republic. I should not just cut them off' (87). In other words, the rail construction is intended to make it easier for his Fulani relatives, who are foreigners, to visit Nigeria, even though many major cities in Nigeria are not connected to the national rail network.

From 2015 to 2018, the federal government of Nigeria increased its efforts to secure free land for Fulani herders through various bills sent to the national assembly meant to be enacted into law. Such efforts were consistent with the concept of resource capture, which entails the inequitable allocation and use of state resources using government instruments to benefit a preferred group to the detriment of others (62). Some of the bills were:

A. National Grazing Reserve (Establishment) Bill, 2015 (HB 448)

B. National Grazing Route and Reserve Commission (Establishment) Bill, 2016 (HB 539).

C. National Grazing Reserves Agency (Establishment) Bill, 2016

These bills did not pass into law owing to the efforts of legislators from the Middle Belt and Southern parts of Nigeria who opposed them. Similarly, on 1st July of 2019, President Buhari came up with a new initiative to solve the eco-violence in Nigeria and termed it 'RUGA Settlement'. President Buhari argued that 'RUGA' will stop eco-violence and will lead to high agricultural productivity and everyone's well-being in Nigeria (88). Once again, the Middle Belt and Southern Nigeria people and their leaders have rejected such policies. In May 2021, the 17 state governors from Southern Nigeria jointly banned open grazing of cattle within their region $(89,90)$. However, on June 10, 2021, President Buhari reiterated his support for open 
grazing in Nigeria and the re-establishment of cattle grazing routes $(91,92)$. These contradictory policies fuel eco-violence. The federal government has the option of enacting legislation to take land from the states, persuading state governors to cede land to the RUGA project, or simply turning a blind eye as militias seize land through violence. The law is on the governors' side because Nigeria's 1978 National Land Use Act vested state governors with the legal authority to manage land within their jurisdictions $(36,66)$. These are classic examples of resource capture mechanisms to favour a group at the detriment of other groups and are among the factors escalating conflict. It instils a sense of deprivation in both the farmers and the Fulani herders, and when it increases, their sense of grievance rises.

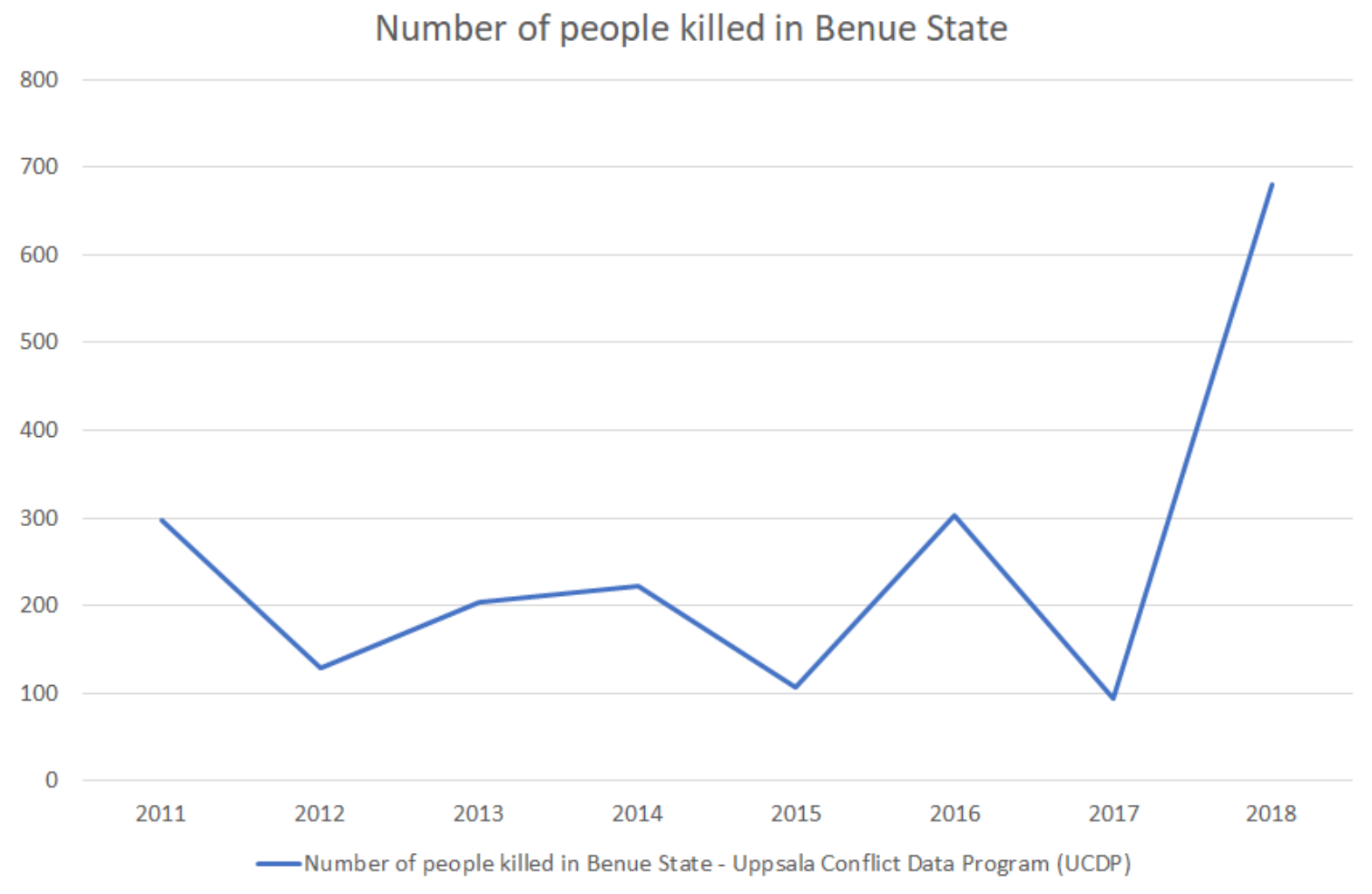

Figure 2.

Source of data: (93)

A causal link between the spate of conflicts and the period the bills for grazing reserves were processed in the legislative house exists. Figure 2 shows a sharp drop in the number of people killed in 2015, but a rise in 2016 when the exercise was unsuccessful. Again, there was a sharp drop between 2016 and 2017 in the fatality rates when new bills were deliberated in parliament. However, when none of the bills passed, there was an increase in the number of incidents and casualties. The escalation during the months of 2018 commenced with the 2018 New Eve killings of about 72 people in Benue state by Fulani herders $(66,94)$.

There have been 'incessant attacks' on communities in Benue state by Fulani militia (43); such escalations in violent attacks were recorded and reported by the Uppsala Conflict Data Program - UCDP (7). The conservative data (93) - see figure 2 - on eco-violence between Fulani herders and Tiv farmers depicts an upsurge in killings since 2014. It shows 298 deaths in 2011, a reduction from 129 deaths in 2012 and an increase to 205 in 2013 and 223 in 2014. In contrast, 107 deaths were recorded in 2015, 303 deaths in 2016, 95 deaths in 2017 and 681 deaths in 2018 and a reduction to 29 deaths in 2019 (93). These available statistics, albeit conservative, depicts intensified attacks in Tiv communities. 
The nepotistic domestic policies of President Buhari did not just justify the grievances of the contending groups but also created a conducive environment for the favoured group - in this case, the Fulani herders - to address their grievances, thus the escalation of eco-violence.

\section{Collaboration between the Elites and Militants}

Some political, economic, security and religious elites have all been accused of collaborating with militants on both sides of the conflict. The escalation of mass violence and killings can occur through the synergy of forces between leaders and militants when most people remain idly in fear and the radical group has won an election (95). In the Nigerian context, this argument seems plausible.

The majority of IDPs interviewed accused the federal government of siding with the Fulani herders and attempting to seize their land on their behalf, blaming this on President Buhari, whom they believe is a Fulani. They, on the other hand, applaud their state government's efforts to alleviate their problems. The Fulani respondents accused the Benue State government of stifling their businesses and lifestyles and not giving them equal rights as citizens, vowing to resist any attempt to stop them from grazing their cattle. Similarly, the former Minister for Defence, General Theophilus Danjuma ${ }^{8}$ urged Nigerians to 'defend yourselves or you will all die' because the security forces in Nigeria are colluding with Fulani herders to attack communities $(96,97)$. A report corroborated the claim that the military collaborated with Fulani herders to kill people (32).

Some religious elites have become bridges between the government and some Fulani herders. For example, Sheikh Ahmad Gumi - a retired army officer - advocates for the herders and assists in ransom negotiations for kidnapped victims (98). Gumi urged President Buhari to grant amnesty to herders (99). Sheikh Gumi accused some segments of the Nigerian military of 'arming' and 'colluding' with the Fulani militia and described the ongoing eco-violence in Nigeria as a 'tribal war' between the Fulani herders and other 'tribes' $(100,101)$. Sheikh Gumi and General Danjuma's assertion of collusion between the military and the herders seems to be a credible one, as both are senior military experts who are neither herders nor farmers, but rather public figures with a reputation to uphold.

The governor of Kaduna State, Mr Nasir El-Rufai, has been accused of taking sides in the ecoviolence involving herders and farmers in Southern Kaduna(102). Mr El-Rufai paid off some Fulani herders - with government funds - not to kill farmers in Southern Kaduna (103). In Benue State, some politicians have been accused of collaborating with Terwase 'Gana' Akwaza (104). The former and incumbent Governors of Benue State, Mr Gabriel Suswan and $\mathrm{Mr}$ Samuel Ortom accused the Nigerian Army of extra-judicial killing of 'Gana' (105). Mr 'Gana' was a 'feared leader' of a Tiv militia group and known to have defended the Tiv people from attacks by Fulani herders and Jukun people; he was also known as a 'dreaded criminal' (104).

Mr Femi Adesina, the spokesperson for the President, Buhari, tacitly supported the Fulani herders when, in an interview on AIT (African Independent TV), he said

Ancestral attachment? You can only have ancestral attachment when you are alive. If you are talking about ancestral attachment, if you are dead, how does the attachment matter? If your state [government] genuinely does not have land for ranching, it is understandable. But where you have land and you can 
do something, please do for peace. What will the land be used for if those who own it are dead at the end of the day? (106).

In other words, the Buhari administration wants people to give up their land for the Fulani herders for peace to reign; if not, they will lose their lives and the land.

Impunity is another issue that the political opportunity structure has engendered; most perpetrators are neither arrested nor prosecuted. The inference of the arguments of some studies in the Nigerian context relates to the opportunities afforded the Fulani herders through the change in government and the benefits of their collaborations with the elites, which offered them the chances to address their grievances against farmers in the Middle Belt $(63,95)$. The mass violence by the Fulani militia caused reprisal attacks by the Tiv militia in solidarity with the farmers, resulting in counter-reprisal attacks from both sides in the absence of a competent and equitable response from the Federal government that controls all the security agencies in Nigeria.

Impunity was identified as a factor escalating the intensity of eco-violence in Benue State by some interviewees. They believe that the perpetrators of the attacks are not being held accountable. For instance, Mr Garius Gololo, the leader of Miyetti Allah in Benue State, who took responsibility for the New Year's Eve attack that killed over 70 people (107). Similarly, a group called the Fulani Nationality Movement (FUNAM) also claimed responsibility for the attempted assassination of Mr Samuel Ortom, the Benue state governor, on the 20th of March 2021 (108). They are yet to be prosecuted.

These narratives show a collaboration between the elites and the militants in the Middle Belt. When the shift in the political opportunity structure advantages a militia, they are prone to commit mass murder and may enjoy impunity, just like the case of the Fulani herders receiving payments from government officials. Whereas, when a militia is constrained by the change in the political opportunity structure, carrying out collection action becomes very expensive and less successful, as in the case of 'Gana'. In this context, the shift in the political opportunity structure offered opportunity and constraints to different groups at the same time. It depicts the precarious nature and implications of nepotistic domestic policies of the government and elite collaborations with militias in these escalating violent conflicts. Those favoured by the political opportunity structure are encouraged and appeased, whereas others are constrained and punished. As a result, the current political opportunity structure in Nigeria favours Fulani herders, who are unleashing terror on Tiv farming communities to address their alleged grievances and gain access to grazing fields, resulting in Tiv retaliation attacks. Thus, the current political opportunity structure does not favour the Tiv farming communities; it disempowers them and even their politicians, and that is why there are cases of frequent mass murder within their communities. These narratives conform to the arguments of HomerDixon's model and are the major factors increasing the unprecedented eco-violence in the Middle Belt.

\section{Conclusion}

By examining the political developments since 2014 in Nigeria and how they connect to the ongoing mass violence in the Middle Belt, this article has increased our understanding of ecoviolence by providing a unique lens to view these conflicts and a deeper understanding of the factors that have fueled their recent escalations in public discourse. 
This article departs from existing literature on the causes of eco-violence to investigate the factors influencing its escalation to unprecedented levels in Nigeria. First, this article foregrounds the current theoretical and empirical debates on eco-violence by engaging with the arguments on environmental resource scarcity, conflict, and migration, then outlining the enhanced Homer-Dixon's model - which underpins the analysis in this article, and finally, by engaging with the extant causes of the conflict. It argues that changes in the political opportunity structure provided opportunities for Fulani herders while impeding Tiv farmers' efforts to carry out collective actions.

It suggests the creation of equitable governance as a way forward to ensure that the next change in political opportunity structure will not favour only a particular section of the country. Equitable governance will be possible if a new and negotiated constitution is created by representatives of the diverse nationalities of Nigerians. Furthermore, if the aftermath of this current political opportunity structure is sustained and not revisited, the consequences of the next political opportunity structure will be catastrophic for Nigeria. 
Disclosure statement

No potential conflict of interest.

ORCID

Ezenwa E. Olumba https://orcid.org/0000-0001-5512-5992 


\section{References}

1. Ejembi R. Benue: Herdsmen attack IDP camp, kill seven, injure [Internet]. Sunnewsonline. 2021 [cited 2021 Jun 14]. Available from:

https://www.sunnewsonline.com/benue-herdsmen-attack-idp-camp-kill-seven-injureothers/

2. Olubajo O. Adopt Ruga if you want peace in Benue, Buhari tells Ortom [Internet]. Pooples Gazette. 2021 [cited 2021 May 2]. Available from: https://gazettengr.com/adopt-ruga-if-you-want-peace-in-benue-buhari-tells-ortom/

3. Uja E. 11 feared killed as suspected herdsmen attack Benue community [Internet]. The Nation. 2021 [cited 2021 May 28]. Available from: https://thenationonlineng.net/11feared-killed-as-suspected-herdsmen-attack-benue-community/

4. Lenshie, N. E., Okengwu, K, Ogbonna, N.C, and Ezeibe C. Desertification, migration, and herder-farmer conflicts in Nigeria: rethinkingthe ungoverned spaces thesis. Small Wars Insur Insur. 2020;1-31.

5. Ilo, U. J., Jonathan-Ichaver, I. and Adamolekun, Y. The Deadliest Conflict You've Never Heard of [Internet]. Foreign Affairs. 2019 [cited 2021 Jan 10]. Available from: https://www.foreignaffairs.com/articles/nigeria/2019-01-23/deadliest-conflict-youvenever-heard

6. Kaldor M. New and Old Wars: Organised Violence in a Global Era. Cambridge: Polity; 2010.

7. Pettersson, T., Högbladh, S. and Öberg M. Organized violence, 1989-2018 and peace agreements. J Peace Res. 2019;56(4):589-603.

8. Münkler H. The New Wars. Cambridge: Polity Press; 2005.

9. O’Malley P. Migration and Conflict. New Engl J Public Policy [Internet]. 2018;30(2):1-15. Available from: https://scholarworks.umb.edu/nejpp/vol30/iss2/14

10. Ajala O. New drivers of conflict in Nigeria: an analysis of the clashes between farmers and pastoralists. Third World Q [Internet]. 2020;41(12):2048-66. Available from: https://doi.org/10.1080/01436597.2020.1811662

11. Kuusaana ED, Bukari KN. Land conflicts between smallholders and Fulani pastoralists in Ghana: Evidence from the Asante Akim North District (AAND). J Rural Stud [Internet]. 2015;42:52-62. Available from: http://dx.doi.org/10.1016/j.jrurstud.2015.09.009

12. Organisation for Economic Co-operation and Development OECD. Case no.1 SenegalMauritania Conflict [Internet]. 2010. Available from: www.oecd.org/countries/mauritania/44650413.pdf

13. Folami OM, Folami AO. Climate Change and Inter-Ethnic Conflict in Nigeria. Peace Rev. 2013;25(1):104-10.

14. Homer-Dixon TF. Environment, Scarcity, and Violence. New Jersey: Princeton University Press; 1999.

15. De Soysa I. Ecoviolence: Shrinking Pie, or Honey Pot? Glob Environ Polit. 2002;2(4):1-34.

16. Parker R. The Senegal-Mauritania conflict of 1989: a fragile equilibrium. J Mod Afr Stud. 1991;29(1155-171). 
17. Nicolaj A. The Senegal Mauritanian Conflict. Africa Riv Trimest di Stud e Doc dell'Istituto Ital per l'Africa e l'Oriente. 1990;45(3):464-80.

18. Cooley JK. The war over water. Foreign Policy. 1984;3-26:3-26.

19. Onwuzuruigbo I. "Even if we Meet in Heaven We Will Fight": British Colonial Policies and Aguleri/Umuleri Conflicts in Southeastern Nigeria. J Asian Afr Stud. 2013;48(2):129-44.

20. Oyeniyi BA. Greed-grievance debate and the Ife-Modakeke conflict. Soc Hist. 2010;35(3):308-29.

21. Tenuche MO. The State, Identity Mobilization and Conflict: A Study of Intra Ethnic Conflict in Ebira Land, North Central - Nigeria intra ethnic conflict in Ebira land, north central -Nigeria. African J Polit Sci Int Relations. 2009;3 (5)(May):253258.

22. Houessou SO, Dossa LH, Diogo RVC, Houinato M, Buerkert A, Schlecht E. Change and continuity in traditional cattle farming systems of West African Coast countries: A case study from Benin. Agric Syst [Internet]. 2019;168(March 2018):112-22. Available from: https://doi.org/10.1016/j.agsy.2018.11.003

23. Thébaud B, Batterbury S. Sahel Pastoralists: Opportunism, Struggle, Conflict and Negotiation: A case study from eastern Niger. Glob Environ Chang. 2001;11(1):6978.

24. Eke S. 'Nomad savage' and herder-farmer conflicts in Nigeria: the (un)making of an ancient myth. Third World Q [Internet]. 2020;41(5):745-63. Available from: https://doi.org/10.1080/01436597.2019.1702459

25. Genyi GA. Ethnic and Religious Identities Shaping Contestation for Land Based Resources: The Tiv-Farmers and Pastoralists Conflicts in Central Nigeria until 2014. J Living Together. 2017;4(1):136-51.

26. Chukwuorji JC, Ifeagwazi CM, Eze JE. Prolonged grief disorder symptoms in bereaved internally displaced Tiv persons in Nigeria: associations with rumination, rebirth concerns and gender. Ment Health Relig Cult [Internet]. 2018;21(6):549-63. Available from:

https://www.tandfonline.com/doi/full/10.1080/13674676.2018.1505838

27. Nwangwu C, Mbah PO, Ike CC, Otu OA, Ezugworie C. Transhumant Pastoral Economy and Human Security in Nigeria: Whither Civil Society Organisations? J Asian Afr Stud. 2020;55(7):1033-53.

28. Ochonu M. Colonialism within colonialism: The Hausa-Caliphate imaginary and the British colonial administration of the Nigerian middle belt. African Stud Q. 2008;10(2-3):95-127.

29. Ioratim-Uba G. Language, ethnicity and conflict: Applying linguistic measure to prevent ethnic violence in middle belt Nigeria. Int J Minor Gr Rights. 2014;21(4):55790 .

30. Akwagyiram A, McNeill R. Nomads and farmers in fight for Nigeria's heartland [Internet]. Reuters. 2018 [cited 2021 Apr 26]. Available from: https://www.reuters.com/article/us-nigeria-security-insight-idUSKBN1OI13X

31. Duerksen M. Nigeria's Diverse Security Threats [Internet]. Africa Center for Strategic Studies. 2021. Available from: https://africacenter.org/spotlight/nigeria-diversesecurity-threats/

32. Amnesty International. Three years of bloody clashes between farmers and herders 
[Internet]. Abuja; 2018. Available from:

https://www.amnesty.org/download/Documents/AFR4495032018ENGLISH.PDF

33. Chijioke Chinwokwu E. GLAMORIZATION OF FULANI HERDSMEN'S CRIMINALITY AND ITS IMPLICATIONS ON NATIONAL SECURITY IN NIGERIA. Vol. 2, Management and Social Sciences (OJAMSS). 2017.

34. Vanger, E.T. and Nwosu BU. Institutional parameters that condition farmer-herder conflicts in Tivland of Benue State, Nigeria. African Secur Rev. 2020;29(1):20-40.

35. International Organization for Migration. Nigeria - North Central And North West Zones Displacement Report 5 [Internet]. International Organization for Migration (IOM). 2021 [cited 2021 May 25]. Available from: https://dtm.iom.int/reports/nigeria-north-central-and-north-west-zones-displacement-report-5-january-2021

36. Ele MN. Transhumance, Climate Change and Conflicts: Reflections on the Legal Implications of Grazing Reserves and Ruga Settlements in Nigeria. J Afr Law. 2020;64(2):199-213.

37. Omilusi MO. Roving terrorists or innocuous cattle grazers. Between herdsmen's economic survival and community annihilation in Nigeris. Cult Relations Q Rev. 2016;3(3):48-76.

38. Ducrotoy MJ, Majekodunmi AO, Shaw APM, Bagulo H, Bertu WJ, Gusi AM, et al. Patterns of passage into protected areas: Drivers and outcomes of Fulani immigration, settlement and integration into the Kachia Grazing Reserve, northwest Nigeria. Pastoralism. 2018;8(1):1-16.

39. Bukari K.N., Sow P. and SJ. Real or Hyped? Linkages Between Environmental / Climate Change and Conflicts - The Case of Farmers and Fulani Pastoralists in Ghana. In: Human and Environmental Security in the Era of Global Risks. Cham: Springer US; 2019. p. 161-85.

40. Bassett T. The Political Ecology of Peasant-Herder Conflicts in the Northern Ivory Coast Author ( s ): Thomas J . Bassett Source : Annals of the Association of American Geographers, Vol . 78 , No . 3 ( Sep ., 1988 ), pp . Published by : Taylor \& amp ; Francis , Ltd. 2008;78(3):453-72.

41. Kuusaana ED, Bukari KN. Land conflicts between smallholders and Fulani pastoralists in Ghana: Evidence from the Asante Akim North District (AAND). J Rural Stud [Internet]. 2015;42:52-62. Available from: http://dx.doi.org/10.1016/j.jrurstud.2015.09.009

42. B. BTA and B. Fulani-Dogon Killings in Mali: Farmer-Herder Conflicts as Insurgency and Counterinsurgency. African Secur. 2021;1-23.

43. Ojo JS. Governing "Ungoverned Spaces" in the Foliage of Conspiracy: Toward (Re)ordering Terrorism, from Boko Haram Insurgency, Fulani Militancy to Banditry in Northern Nigeria. African Secur. 2020;13(1):77-110.

44. Mbih RA. The politics of farmer-herder conflicts and alternative conflict management in Northwest Cameroon. African Geogr Rev. 2020;39(4):324-44.

45. Bamidele S. A tale of two communities: Who owns the land? community safety, peace process and land ownership in tiv/jukun communities of Taraba State, Nigeria. GeoJournal [Internet]. 2020;5. Available from: https://doi.org/10.1007/s10708-02010339-5

46. Nwozor, A., Olanrewaju, J.S., Oshewolo, S., Oladoyin, A.M., Adedire, S. and Okidu 
O. Herder-Farmer Conflicts: The Politicization of Violence and Evolving Security Measures in Nigeria. African Secur. 2021;1-25.

47. Nwankwo CF. Discursive construction of the farmer-pastoralist conflict in Nigeria. Open Polit Sci. 2021;4(1):136-46.

48. Tilly, C. and Tarrow S. Contentious Politics. Oxford: Oxford University Press; 2015.

49. Hagmann T. Confronting the concept of environmentally induced conflict. Peace, Confl Dev [Internet]. 2005;6(6):1-22. Available from:

http://se2.isn.ch/serviceengine/Files/EINIRAS/15430/ipublicationdocument_singledoc ument/1F31F218-C9AE-45D7-B874-FA28E070EDE4/en/hagmann.pdf

50. Gleditsch, N.P. and Urdal H. Ecoviolence? Links between population growth, environmental scarcity and violent conflict in Thomas Homer-Dixon's work. J Int Aff. 2002;56(1):283-302.

51. Matthew RA. Environment, Population and Conflict: New Modalities of Threat and Vulnerability in South Asia. J Int Aff. 2002;56(1):235-54.

52. Levy MA. Is the environment a national security issue? Int Secur. 1995;20(2):35-62.

53. Binningsbø HM, de Soysa I, Gleditsch NP. Green giant or straw man? Environmental pressure and civil conflict, 1961-99. Popul Environ. 2007;28(6):337-53.

54. Urdal H. Population, Resources, and Political Violence. 2008;(590):590-617.

55. Raleigh C, Jordan L, Salehyan I. Assessing the Impact of Climate Change on Migration and Conflict. Soc Dev Dep World Bank Gr [Internet]. 2008;1-57. Available from:

http://siteresources.worldbank.org/EXTSOCIALDEVELOPMENT/Resources/SDCC WorkingPaper_MigrationandConflict.pdf

56. Bukari KN, Sow P, Scheffran J. Cooperation and Co-Existence Between Farmers and Herders in the Midst of Violent Farmer-Herder Conflicts in Ghana. Afr Stud Rev. 2018;61(2):78-102.

57. Barnett JON. Destabilizing the environment - conflict thesis. 2000;5:271-88.

58. de Coning CH, Florian K, Yaw Tchie AE, Grand AO, Tarif K. Climate, Peace and Security Fact Sheet Sahel [Internet]. 2021. Available from:

https://www.nupi.no/en/Publications/CRIStin-Pub/Climate-Peace-and-Security-FactSheet-Sahel

59. Mbaye AA. Climate Change, Livelihoods, and Conflict in the Sahel. Georg J Int Aff. 2020;21(1):12-20.

60. Homer-Dixon, T. and Blitt J. Introduction: A Theoretical Overview. In: Ecoviolence: links among environment, population, and security. New york: Rowman \& Littlefield Publishers; 1998. p. 1-17.

61. Nasong'o W. Explaining Ethnic Conflicts Theoretical and Conceptual Perspectives. In: W. Nasong'o, editor. The roots of ethnic conflict in Africa: From grievance to violence. New York, NY: Palgrave Macmillan; 2015. p. 11-20.

62. Percival VAL, Homer-dixon T. Environmental Scarcity and Violent Conflict: The Case of South Africa Author ( $\mathrm{s}$ ): Val Percival and Thomas Homer-Dixon Source : Journal of Peace Research, Vol . 35 , No . 3 , Special Issue on Environmental Conflict Stable URL : http://www.jstor.org/sta. J Peace Res. 1998;35(3):279-98.

63. Tarrow SG. Power in Movement: Social Movements and Contentious Politics. 
Cambridge: Cambridge University Press; 1998.

64. Okoli AC, Ogayi CO. Herdsmen militancy and humanitarian crisis in Nigeria: A theoretical briefing. African Secur Rev [Internet]. 2018;27(2):129-43. Available from: https://doi.org/10.1080/10246029.2018.1499545

65. Olaniyan A, Francis M, Okeke-Uzodike U. The cattle are "Ghanaians" but the herders are strangers: Farmer-herder conflicts, expulsion policy, and pastoralist question in Agogo, Ghana. African Stud Q. 2015;15(2):53-67.

66. Sule PE. Open grazing prohibitions and the politics of exclusivist identity in Nigeria. Africa Rev [Internet]. 2020;0(0):1-17. Available from: https://doi.org/10.1080/09744053.2020.1812041

67. Ogbette AS, Attama AO, Okoh JO. Fulani-Herders and Farmers Crises Under Buhari's Administration-Causes, Effects and Its Management. Int J Peace Confl Stud. 2018;5(2):44-53.

68. Sayne A. Rethinking Nigeria's Indigene-settler Conflicts. 2012.

69. Chukwuma KH. Constructing the Herder-Farmer Conflict as (in)Security in Nigeria. African Secur [Internet]. 2020;13(1):54-76. Available from: https://doi.org/10.1080/19392206.2020.1732703

70. Creswell, J.W. and Creswell JD. Research design: Qualitative, quantitative, and mixed methods approaches. Thousand Oaks, CA: Sage Publications; 2018.

71. Braun V, Clarke V. Using thematic analysis in psychology. Qual Res Psychol. 2006;3(2):77-101.

72. Lewis, P. and Kew D. Nigeria's hopeful election. Journal of Democracy. J Democr. 2015;26(3):94-109.

73. Owen, O. and Usman Z. Briefing: Why Goodluck Jonathan lost the Nigerian presidential election of 2015. Afr Aff (Lond). 2015;114(456):455-75.

74. Bappah HY. Nigeria's military failure against the Boko Haram insurgency. African Secur Rev. 2016;25(2):146-58.

75. Ogbogu J. Analysing the Threat of Boko Haram and the ISIS Alliance in Nigeria. Count Terror Trends Anal. 2015;7(8):16-21.

76. Eizenstat SE, Porter JE, Weinstein JM. Rebuilding weak states. Foreign Aff. 2005;84(1):134-46.

77. Amnesty International. Three years of bloody clashes between farmers and herders [Internet]. Amnesty International. 2018 [cited 2020 May 4]. Available from: https://www.amnesty.org/download/Documents/AFR4495032018ENGLISH.PDF

78. Peace I for E and. Global Terrorism Index 2015 [Internet]. 2015. Available from: http://economicsandpeace.org/wp-content/uploads/2015/11/2015-Global-TerrorismIndex-Report.pdf

79. United States Institute of Peace. Nigeria: A Conversation with President Muhammadu Buhari [Internet]. United States Institute of Peace. 2015 [cited 2019 Sep 10]. Available from: https://www.usip.org/events/nigeria-conversation-president-muhammadu-buhari

80. Fasan O. Balanced or lopsided? The truth about Buhari's appointments [Internet]. Vanguard Newspaper. 2020 [cited 2021 Feb 1]. Available from: https://www.vanguardngr.com/2020/07/balanced-or-lopsided-the-truth-about-buharisappointments/ 
81. Opejobi S. Buhari under fire for giving 'strategic' appointments to Fulani, Hausa, Kanuri [Internet]. Daily Post Newspaper. 2020 [cited 2021 Jun 23]. Available from: https://dailypost.ng/2020/05/21/buhari-under-fire-for-giving-strategic-appointmentsto-fulani-hausa-kanuri/

82. Demarest, L., Langer, A. and Ukiwo U. Nigeria's Federal Character Commission (FCC): a critical appraisal. Oxford Dev Stud. 2020;48(4):315-28.

83. Oluwasanmi B. Senate President Ahmed Lawan And Fulani Barbarians [Internet]. Sahara Reporters. 2021 [cited 2021 May 29]. Available from:

http://saharareporters.com/2021/04/07/senate-president-ahmed-lawan-and-fulanibarbarians-bayo-oluwasanmi

84. Kporegi F. "Fulanization" of the North by the South [Internet]. farooqkperogi. 2021 [cited $2021 \mathrm{Jul} 2$ ]. Available from:

https://www.farooqkperogi.com/2021/06/fulanization-of-north-by-south.html

85. Kraxberger B. Strangers, indigenes and settlers: Contested geographies of citizenship in Nigeria. Sp Polity. 2005;9(1):9-27.

86. Clowes W. Nigeria Taps StanChart to Replace China Loans for Rail Projects [Internet]. Bloomberg. 2021 [cited 2021 Jul 1]. Available from:

https://www.bloomberg.com/news/articles/2021-06-10/nigeria-taps-stanchart-toreplace-china-loans-for-rail-projects

87. Ayomide C. Buhari defends Niger Republic rail project, says 'I have family members there", ' [nternet]. Peoples Gazette. 2021 [cited 2021 Jul 2]. Available from:

https://gazettengr.com/buhari-defends-niger-republic-rail-project-says-i-have-familymembers-there/

88. Agbakwuru J. Ruga Settlement: It's true FG gazetted land in 36 States - Presidency [Internet]. Vanguard Newspaper. 2019 [cited 2021 Jul 5]. Available from:

https://www.vanguardngr.com/2019/06/ruga-settlement-its-true-fg-gazetted-land-in36-states-presidency/

89. Ahon, F., Agbakwuru, J. and Iheamnachor D. Insecurity: Southern Governors offer 10point solution [Internet]. Vanguard Newspaper. 2021 [cited 2021 May 29]. Available from: insecurity: Southern Governors offer 10-point solution https://www.vanguardngr.com/2021/05/insecurity-southern-governors-offer-10-pointsolution

90. Kabir A. Analysis: How southern governors' ban on open grazing may reduce farmerherder crisis [Internet]. Premium Times Nigeria. 2021 [cited 2021 Jul 2]. Available from: https://www.premiumtimesng.com/news/headlines/462883-analysis-howsouthern-governors-ban-on-open-grazing-may-reduce-farmer-herder-crisis.html

91. Akinkuotu E. Buhari backs open grazing, asks AGF to recover land for herdsmen [Internet]. Punch Nigeria. 2021 [cited 2021 Jul 2]. Available from: https://punchng.com/buhari-backs-open-grazing-asks-agf-to-recover-land-forherdsmen/

92. Jimoh, A. M., Daka, T., Njoku and AA. Buhari: FG will reclaim grazing routes for herders [Internet]. Guardian Nigeria. 2021 [cited 2021 Jul 2]. Available from: https://guardian.ng/news/buhari-fg-will-reclaim-grazing-routes-for-herders/

93. Uppsala Conflict Data Program (UCDP). Fulani-Tiv [Internet]. Uppsala University. [cited 2021 Mar 30]. Available from: https://ucdp.uu.se/additionalinfo/4973/1 
94. Adebayo, B. and Busari S. Benue killings: Mass burial held for dozens killed in New Year's day attacks [Internet]. CNN. 2018 [cited 2021 Apr 24]. Available from: https://edition.cnn.com/2018/01/11/africa/benue-killings-mass-burial/index.html

95. Mann M. The dark side of democracy: Explaining ethnic cleansing. Cambridge: Cambridge University Press; 2006.

96. Mkom J. Defend yourselves or you will all die, TY Danjuma tells Nigerians [Internet]. Vanguard Newspaper. 2018 [cited 2021 Apr 27]. Available from: https://www.vanguardngr.com/2018/03/defend-will-die-ty-danjuma-tells-nigerians/

97. Viashima S. Herders attacks: Defend yourselves, Gen. Danjuma tells Nigerians [Internet]. Sunnewsonline. 2018 [cited 2021 Apr 27]. Available from: https://www.sunnewsonline.com/herders-attacks-defend-yourselves-gen-danjumatells-nigerians/ \%0A

98. Akinrefon, D. and Ajayi O. Insecurity: Fulani herdsmen aren't bandits but militants fighting ethnic war - Sheik Gumi [Internet]. Vanguard Newspaper. 2021 [cited 2021 Jul 4]. Available from: https://www.vanguardngr.com/2021/02/insecurity-fulaniherdsmen-arent-bandits-but-militants-fighting-ethnic-war-sheik-gumi/

99. Channels TV. Bandits Are Ready To Negotiate And Be Incorporated Into Society Gumi [Internet]. Channels TV. Nigeria; 2021 [cited 2021 Jul 1]. Available from: https://www.channelstv.com/2021/03/25/bandits-are-ready-to-negotiate-and-beincorporated-into-society-gumi/

100. Maishanu AA. I was not invited by SSS - Gumi [Internet]. Premium Times Nigeria. [cited $2021 \mathrm{Jul}$ 3]. Available from: https://www.premiumtimesng.com/news/headlines/470025-i-was-not-invited-by-sssgumi.html \%0A

101. Nwezeh, K., Okonji, E. and Alekhuogie N. We Have Tribal War on Our Hands, Says Gumi [Internet]. Thisday Newspapers Online. [cited 2021 Jun 29]. Available from: https://www.thisdaylive.com/index.php/2021/06/24/we-have-tribal-war-on-our-handssays-gumi/

102. Agande B. Catholic Church blames El-Rufai for southern Kaduna killings [Internet]. Vanguard Newspaper. 2017 [cited 2021 Apr 24]. Available from: https://www.vanguardngr.com/2017/04/catholic-church-blames-el-rufai-southernkaduna-killings/

103. Channels Television. El-Rufai Speaks On Southern Kaduna Crisis Pt 3 [Internet]. Nigeria; 2017. Available from: https://www.youtube.com/watch?v=f0KZGbGFwho

104. Okoh G. Fall of the Notorious Gana in Benue State [Internet]. Thisday Newspapers Online. 2020 [cited 2020 May 27]. Available from: https://www.thisdaylive.com/index.php/2020/09/12/fall-of-the-notorious-gana-inbenue-state/

105. Ayitogo N. Controversy trails killing of Benue's 'most wanted' criminal, Gana Controversy trails killing of Benue's 'most wanted' criminal, Gana [Internet]. Premium Times Nigeria. 2020 [cited 2021 Apr 4]. Available from: https://www.premiumtimesng.com/news/headlines/413503-controversy-trails-killingof-benues-most-wanted-criminal-gana.html

106. Aziken, E., Agbo, D. Giving land for ranching better than death [Internet]. Vanguard Newspaper. 2018 [cited 2021 Jun 14]. Available from: https://www.vanguardngr.com/2018/07/giving-land-ranching-better-death-presidency/ 
107. Yawe E. Consequences of Endless Bloody Clashes in the Benue Valley [Internet]. Thisday Newspapers Online. 2018 [cited 2019 Nov 16]. Available from: https://www.thisdaylive.com/index.php/2018/05/27/consequences-of-endless-bloodyclashes-in-the-benue-valley/

108. Ewubare K. Why We Tried to Kill Ortom, Militia Group Claims Responsibility for Attack on Nigerian Governor [Internet]. Legit Nigeria. 2021 [cited 2021 May 29]. Available from: https://www.legit.ng/1408263-why-kill-ortom-militia-group-claimsresponsibility-attack-nigerian-governor.html

Notes

\footnotetext{
1 'RUGA' is a Federal Government of Nigeria policy aimed at securing free land and grazing settlements for Fulani herders from Nigeria's 36 state governments.

${ }^{2}$ Figures calculated from data received from the Nigerian Investment Promotion Commission, 2018.

${ }^{3}$ Known figures are conservative estimates and many cases go unreported.

${ }^{4}$ The report was the research output of researchers at the Norwegian Institute of International Affairs (NUPI) and the Stockholm International Peace Research Institute (SIPRI).

${ }^{5}$ President Buhari came to power on 31 December 1983 after successfully overthrowing the government of Alhaji Shehu Shagari.

${ }^{6}$ The event was at the U.S. Institute of Peace offices in Washington, DC., less than two months after being sworn in as President.

${ }^{7}$ For a list of new members of the FCC appointed on 27th April 2021, see Shibayan (2020).

${ }^{8} \mathrm{He}$ was a senior military officer and among those who carried out the counter-coup in 1966. He was on Forbes' richest list in 2015 with a net worth of $\$ 750$.
} 